\title{
Revue burkinabè de droit
}

Revue semestrielle. No 14 (Juillet 1988), 180 p. Pour l'Afrique: Ecole supérieure de droit, Université de Ouagadougou, B.P. 7021, Ouagadougou, Burkina Faso, 5.000 CFA. Pour l'Europe: Faculté de droit, Rempart de la Vierge, 5, B-5000 Namur, Belgique, 700 FB (100 FF)

La Revue burkinabè de droit se présente d'une part comme un forum de discussion des problèmes juridiques les plus fondamentaux liés au système politique, économique et social du Burkina Faso et d'autre part comme un organe de publication de la jurisprudence des hautes cours de ce pays.

Les articles de doctrine dans le numéro du 14 juillet 1988 sont consacrés à trois domaines essentiels non seulement pour le Burkina Faso mais aussi pour un bon nombre de pays africains.

Le premier article traite des aspects juridiques de la restructuration des sociétés commerciales. Confronté à une crise économique grave l'État burkinabè a vu la nécessité de relancer l'activité économique nationale, et plus spécialement l'industrie. Par la suite, il a décrété la transformation des Entreprises privées, en cessation d'activité ou même simplement en difficulté, en Sociétés d'économie mixte. Dans un premier temps la restructuration a été un transfert progressif des moyens de production du privé à l'État. Ce changement externe a été suivi par une redistribution des pouvoirs au sein des sociétés commerciales. Par les ordonnances du 15 août 1984, régissant les Sociétés d'État et les Sociétés d'économie mixte, une représentation égalitaire des travailleurs et des actionnaires aussi bien dans les Conseils d'Administration que dans les Assemblées d'Actionnaires a été assurée. L'article décrit ensuite les aspects juridiques de cette participation de la puissance publique au capital des sociétés et de son exercice d'un contrôle dérogatoire aux règles du droit commercial ainsi que les problèmes liés à cette "démocratisation" interne.

Les deux articles suivants sont consacrés aux problèmes qui ont une importance similaire dans les États africains - le combat contre le détoumement de deniers et la décentralisation de l'administration dans le but de faire participer la population à la politique de construction nationale.

Dans sa deuxième partie la Revue contient un rapport de la jurisprudence de la Cour d'appel de Ouagadougou et de Bobo-Dioulasso ainsi que de la Haute Cour d'État. Les décisions couvrent tous les domaines de droit - droit civil, judiciaire, commercial, pénal, administratif et droit social. Elles englobent des problèmes de la vie quotidienne comme l'accident de circulation, la vente d'un véhicule, le divorce ou les contrats de travail ainsi que des sujets qui vont plus au fond de la structure d'État en touchant la question de la séparation de pouvoir entre l'administration et la jurisprudence. Les décisions sont suivies par des notes qui soulignent les points les plus frappants en commentant et critiquant la position prise par la cour.

Mais la présentation de la Revue burkinabè de droit ne serait pas complète sans avoir mentionné la bibliographie de droit burkinabè figurant à la fin de ce journal. Avec 450 
références les auteurs donnent une vue d'ensemble sur le droit (écrit et coutumier) burkinabè, sur la jurisprudence, sur les projets de code, sur les rapports des séminaires et des groupes de travail touchant les domaines divers de droit et sur la doctrine (thèses, mémoires, articles, notes de jurisprudence). C'est une collection d'information impressionante et fondamentale pour le développement et la défense du droit au service de l'intérêt commun.

Gabriele Oestreich

\section{Jürgen Rüland (ed.)}

Urban Government and Development in Asia: Readings in Subnational Development (Materialien zu Entwicklung und Politik 33)

München, Köln, London, Weltforum-Verlag, 1988, iv + 270 p., DM 49,-

Compared to other fields of development research, local government has received relatively little scholarly attention. For a long time local government research in Third World countries was the pre-occupation of specialists working in the field of public administration and development management, whereas, unlike in Northern America and Europe, political scientists have chosen to neglect the topic. Even today, theories on local govermment in developing countries are virtually non-existent. But even less ambitious endeavors, such as attempts to classify and systematize phenomena and processes of local government beyond their legal-formal framework, are not frequently encountered in existing literature. In the absence of a good stock of comparative studies, the eclectical case study still remains the predominant species of Southeast Asian local government research.

This reader, edited by Jürgen Rüland, author of numerous publications on local government, urbanization, political and socio-economic affairs in Southeast Asia, endeavors to stimulate the debate on this long neglected field. This book brings together practitioners and scholars with various professional backgrounds such as law, political science, urban planning, public administration and economics. Hence, the diversity of methodological premises which also accounts for the lack of uniform argumentation among the various articles. Different viewpoints are offered: sometimes to the extent that they even appear to be contradictory. This reader provides a detailed discussion of existing approaches to the study of urban government in Asia and pleads for new theoretical and conceptional directions. Apart from traditional issues such as central-local relations, finance, planning, personnel management and citizen participation, this book also tackles new themes such as urban environmental problems and information management capacities of local governments. 